\title{
Carbamylated albumin stimulates microRNA-146, which is increased in human renal cell carcinoma
}

\author{
EUNYOUNG HA ${ }^{1}$, JI-HYE BANG ${ }^{1}$, JUNG NAM SON $^{1}$, HO-CHAN CHO ${ }^{2}$ and KYO-CHUL MUN ${ }^{1}$ \\ ${ }^{1}$ Department of Biochemistry and Kidney Institute, School of Medicine, Keimyung University; \\ ${ }^{2}$ Department of Internal Medicine, Daegu Medical Center, Daegu, Korea
}

Received September 20, 2009; Accepted November 25, 2009

DOI: 10.3892/mmr_00000251

\begin{abstract}
Carbamylation is a post-translational modification, the pathophysiological consequences of which remain poorly understood. MicroRNAs (miRNAs) are endogenous non-coding small ribonucleic acids that have emerged as one of the central players in gene expression regulation. This study was designed to determine the effect of carbamylated albumin (cAlb) on the expression of miRNAs. Albumin was carbamylated, and the extent of carbamylation was monitored using trinitrobenzenesulphonic acid. Albumin or cAlb were added to rat mesangial cells (RMCs), and RNA was extracted. miRNA microarray analysis was performed. The expression of microRNA-146a (miR-146a) and microRNA-146b (miR-146b) was analyzed by real-time RT-PCR. Of 365 miRNAs analyzed, the expression of $\mathrm{miR}-146 \mathrm{a} / \mathrm{b}$ was found to be markedly induced by cAlb (miR-146a, 12.75-fold increase; miR-146b, 5.88-fold increase). Real-time RT-PCR analysis confirmed the increased levels of miR-146a/b by cAlb $(\mathrm{p}<0.05)$. It was also found that expression levels of $\mathrm{miR}-146 \mathrm{a} / \mathrm{b}$ were increased in renal cell carcinoma tumor tissues compared to corresponding non-tumor tissues $(\mathrm{p}<0.05)$. Our data suggest that cAlb stimulates miR-146a/b in RMCs, the levels of which are increased in renal cell carcinoma. Further studies on the function of cAlb may provide new insights into the pathophysiology of renal cell carcinoma.
\end{abstract}

\section{Introduction}

Cyanate $\left(\mathrm{OCN}^{-}\right)$, a reactive species in equilibrium with urea, carbamylates protein lysine residues to form $\varepsilon$-carbamyllysine (homocitruline), altering protein structure and function. A potential role for carbamylation in the post-translational modification of proteins in human health and disease has thus far been investigated solely in the context of uremia (1-4). Recently, an alternative and dominant mechanism for cyanate

Correspondence to: Dr Kyo-Chul Mun, Department of Biochemistry and Kidney Institute, School of Medicine, Keimyung University, Daegu 700-712, Korea

E-mail: hanne.md@gmail.com; eyha@dsmc.or.kr

Key words: carbamylation, albumin, microRNA, renal cell carcinoma formation and protein carbamylation at sites of inflammation has been reported. This study confirms that cyanate is produced by myeloperoxidase (MPO), a heme protein abundantly expressed in polymorphonuclear neutrophils (PMNs), and that cyanate-mediated protein carbamylation occurs under physiologically relevant conditions (5).

MicroRNAs (miRNAs) are a family of approximately 22-nucleotide non-coding RNAs identified in organisms ranging from nematodes to humans (6-8). Many miRNAs are evolutionarily conserved across phyla, regulating gene expression by post-transcriptional gene repression. miRNAs regulate gene expression by binding the 3-untranslated region of their target messenger RNAs (mRNAs), leading to translational repression or mRNA degradation. Several miRNAs exhibit a tissue-specific or developmental stage-specific expression pattern and have been reported to be associated with human diseases such as cancer, leukemia, cardiovascular disorders and inflammatory diseases (9-11).

Although it has been documented that the carbamylation of albumin, the most abundant serum protein, occurs in renal dysfunction, few studies regarding the potential involvement of carbamylated albumin (cAlb) in renal pathophysiology have been reported. However, a recent study showed that cAlb is a potent inhibitor of PMN respiratory bursts, implicating a potential regulatory role of cAlb in the host defense system (12). Thus, this study aimed to identify the effect of cAlb by determining cAlb-mediated differential expression of miRNAs.

\section{Materials and methods}

Cell culture. A monolayer of rat mesangial cells (RMCs) was maintained at subconfluent conditions in growth media containing DMEM with $4.5 \mathrm{~g} / \mathrm{l}$ glucose, $100 \mathrm{U} / \mathrm{ml}$ penicillin, $100 \mu \mathrm{g} / \mathrm{ml}$ streptomycin and $10 \%$ fetal bovine serum. Cells were grown in a humidified incubator at $37^{\circ} \mathrm{C}$ with ambient oxygen and $5 \% \mathrm{CO}_{2}$.

Tissue samples. Renal cell carcinoma specimens that included both tumor and non-tumor lesions were provided by the Keimyung Human Bio-Resource Bank, a member of the National Biobank of Korea, which is supported by the Ministry of Health, Welfare and Family Affairs. All samples derived from the National Biobank of Korea were obtained 
with informed consent under institutional review board (IRB)approved protocols.

Carbamylation. Human albumin (Sigma, MO, USA) was carbamylated as described previously (13). Briefly, albumin was incubated at $37^{\circ} \mathrm{C}$ with $0.2 \mathrm{M}$ potassium cyanate (KCNO) for 1, 2, 4 and $8 \mathrm{~h}$, followed by dialysis. Albumin was also carbamylated by incubation at $37^{\circ} \mathrm{C}$ with $8,16,125,1,000$ or $2,000 \mathrm{mM}$ cyanate for $8 \mathrm{~h}$. cAlb was then extensively dialyzed against 121 of phosphate-buffered saline at $\mathrm{pH} 7.4$ at $4^{\circ} \mathrm{C}$ to remove excess cyanate. Buffer $(21)$ was exchanged every $4 \mathrm{~h}$ for $12 \mathrm{~h}$. After $12 \mathrm{~h}, 4 \mathrm{l}$ of dialysis solution was exchanged every $8 \mathrm{~h}$ for $16 \mathrm{~h}$. After dialysis, protein content was measured. cAlb protein $(170 \mu \mathrm{g})$ was dissolved in $1 \mathrm{ml}$ of normal saline and was used for the reaction with trinitrobenzenesulphonic acid. The extent of carbamylation was monitored by following the loss of free amino groups using trinitrobenzenesulphonic acid. Trinitrobenzenesulphonic acid 0.1\% (50 $\mu \mathrm{l})$ was added to $1 \mathrm{ml}$ of albumin (500 U/ml in normal saline) and $1 \mathrm{ml}$ of $4 \%$ sodium hydrogen carbonate, $\mathrm{pH} 8.4$, and this was incubated for $1 \mathrm{~h}$ at $37^{\circ} \mathrm{C}$. Absorbance was then measured at $340 \mathrm{~nm}$ against a blank sample, and the trinitrobenzenesulphonic acid reactivity was expressed as a percentage of the absorbance obtained for the non-carbamylated albumin. Electrophoresis of the control and cAlb was performed on a $10 \%$ polyacrylamide gel.

RNA extraction and miRNA microarray analysis. Total RNAs of RMCs treated with albumin $(500 \mu \mathrm{g} / \mathrm{ml})$ or cAlb (100 and $500 \mu \mathrm{g} / \mathrm{ml}$ ) and renal cell carcinoma specimens were extracted with TRIzol reagents (Gibco, Grand Island, NY, USA) according to the manufacturer's protocol. For control and test RNAs, the synthesis of target miRNA probes and hybridization were performed using the Agilent miRNA Labeling Reagent and Hybridization kit (Agilent Technology, Palo Alto, CA, USA) according to the manufacturer's instructions. Briefly, each $100 \mathrm{ng}$ of total RNA was dephosphorylated with $\sim 15 \mathrm{U}$ of calf intestine alkaline phosphatase, followed by RNA denaturation with $\sim 40 \%$ DMSO and a 10 -min incubation at $100^{\circ} \mathrm{C}$. Dephosphorylated RNA was ligated with pCp-Cy3 mononucleotide and purified with MicroBioSpin 6 columns (Bio-Rad, USA). After purification, labeled samples were resuspended with a gene expression blocking reagent and Hi-RPM hybridization buffer, followed by boiling for $5 \mathrm{~min}$ at $100^{\circ} \mathrm{C}$ and 5 min chilling on ice. Finally, denatured labeled probes were pipetted onto the assembled Agilent miRNA microarray $(15 \mathrm{~K})$ and hybridized for $20 \mathrm{~h}$ at $55^{\circ} \mathrm{C}$ with $20 \mathrm{RPM}$ rotation in an Agilent Hybridization Oven (Agilent Technology). The hybridized microarrays were washed according to the manufacturer's washing protocol (Agilent Technology).

Data acquisition and analysis. The hybridized images were scanned using the Agilent DNA Microarray Scanner, and quantified with Feature Extraction Software (Agilent Technology). Data normalization and the selection of foldchanged genes were performed using GeneSpringGX 7.3 (Agilent Technology). The averages of the normalized ratios were calculated by dividing the average of the normalized signal channel intensity by the average of the normalized control channel intensity.

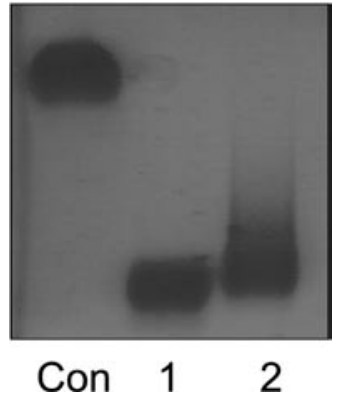

Figure 1. Gel electrophoresis for non-carbamylated albumin (Con) and carbamylated albumin (1, 50\% carbamylated albumin; $2,43 \%$ carbamylated albumin).

Real-time RT-PCR. Real-time reverse transcription-polymerase chain reaction (RT-PCR) was performed for quantitative analysis according to the standard protocol using the GenoExplorer microRNA qRT-PCR kit (Genosensor Corp., AZ, USA). MicroRNA primer pairs used for the experiments were purchased from Genosensor Corp. Real-time PCR was performed using the three-step reaction protocol. Total RNA was extracted using TRI reagent (Invitrogen Co., USA) at $37^{\circ} \mathrm{C}$ for $30 \mathrm{~min}$, and was heated at $95^{\circ} \mathrm{C}$ for $5 \mathrm{~min}$. Complementary DNA (cDNA) was synthesized from $1 \mu \mathrm{g}$ total RNA using the first-strand cDNA Core Kit-50 (Genosensor Corporation) at $42^{\circ} \mathrm{C}$ for $60 \mathrm{~min}$ and $95^{\circ} \mathrm{C}$ for 5 min. Real-time PCR parameters used were as follows: $94^{\circ} \mathrm{C}$ for $15 \mathrm{~min}$, then 50 cycles performed at $94^{\circ} \mathrm{C}$ for $30 \mathrm{sec}, 59^{\circ} \mathrm{C}$ for $15 \mathrm{sec}$ and $72^{\circ} \mathrm{C}$ for $30 \mathrm{sec}$, followed by a 10 -min extension at $72^{\circ} \mathrm{C}$ for $1 \mathrm{~min}$ at $40^{\circ} \mathrm{C}$ for $30 \mathrm{sec}$. The samples were assayed on a LightCycler LC II instrument (Roche Diagnostics GmbH, Germany), and the concentration was calculated as copies per microliter using the standard curve.

Statistical analysis. Statistical analysis was performed using the Student's t-test and one-way analysis of variance (ANOVA). The accepted level of significance was set at a p-value of $<0.05$. Data are presented as the mean \pm standard deviation (SD). The SAS Statistical Software Package (release 8.02; SAS Institute Inc., Cary, NC, USA) was used.

\section{Results}

Verification of albumin carbamylation. Albumin (Alb) was carbamylated for various time periods (1, 2, 4, 8 and 24 h), and the degree of carbamylation was evaluated by trinitrobenzenesulphonic acid analysis. The results indicated that $\mathrm{Alb}$ was most extensively carbamylated, in the range of $43-50 \%$, when incubated for $8 \mathrm{~h}$ (data not shown). Fig. 1 demonstrates the electrophoretic mobility of Alb and cAlb incubated with KCNO for $8 \mathrm{~h}$. The electrophoretic mobility of cAlb was more rapid than that of Alb. In the following experiments, Alb carbamylated for $8 \mathrm{~h}$ was used.

Effect of cAlb on miRNA expression in rat mesangial cells. In preliminary experiments, we confirmed that neither Alb or cAlb exerted a toxic effect on RMCs at the dosages employed in this study (100-500 $\mu \mathrm{g} / \mathrm{ml}$ ) (data not shown). Subsequently, in order to assess the expression profiles of RMCs treated 
Table I. Up-regulated miRNAs in Alb- or cAlb-treated rat mesangial cells.

\begin{tabular}{lcccc}
\hline miRNAs & Alb $(500 \mu \mathrm{g} / \mathrm{ml})$ & $\mathrm{cAlb}(100 \mu \mathrm{g} / \mathrm{ml})$ & $\mathrm{cAlb}(500 \mu \mathrm{g} / \mathrm{ml})$ & Accessions \\
\hline rno-miR-146a & 2.98 & 7.10 & 12.75 & mirlmo-miR-146almirlMIMAT0000852 \\
rno-miR-146b & 1.67 & 4.13 & 5.88 & mirlmo-miR-146blmirlMIMAT0005595 \\
rno-miR-21 & 1.82 & 4.40 & 5.04 & mirlmo-miR-21* ${ }^{*}$ mirlMIMAT0004711 \\
rno-miR-21 & 2.37 & 3.13 & 2.14 & mirlmo-miR-21 ImirlMIMAT0000790 \\
rno-miR-222 & 2.09 & 2.61 & 3.59 & mirlmo-miR-21lmirlMIMAT0000790 \\
\hline
\end{tabular}

miRNAs, microRNAs; Alb, albumin; cAlb, carbamylated albumin.

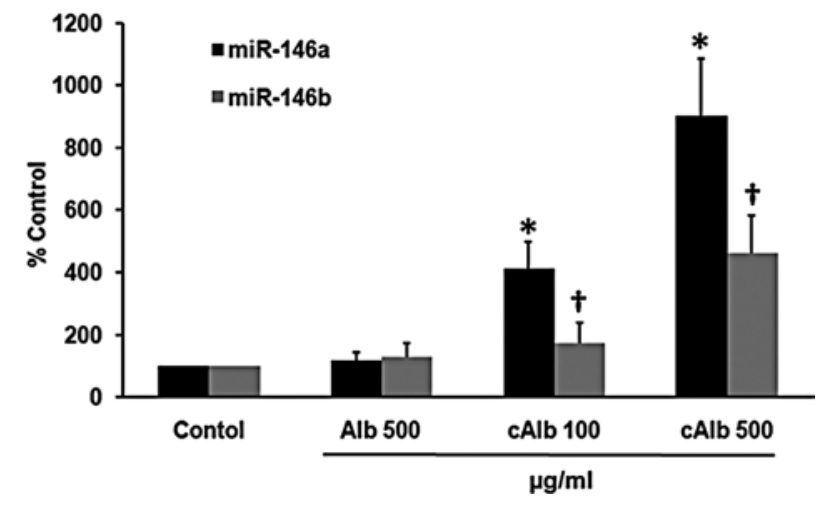

Figure 2. Effect of albumin (Alb $500 \mu \mathrm{g} / \mathrm{ml}$ ) and carbamylated albumin (cAlb $100 \mu \mathrm{g} / \mathrm{ml}$ and cAlb $500 \mu \mathrm{g} / \mathrm{ml}$ ) on the expression levels of miR-146a and miR-146b ("p $<0.05$ vs. control miR-146a; ${ }^{\dagger} \mathrm{p}<0.05$ vs. control miR-146b).

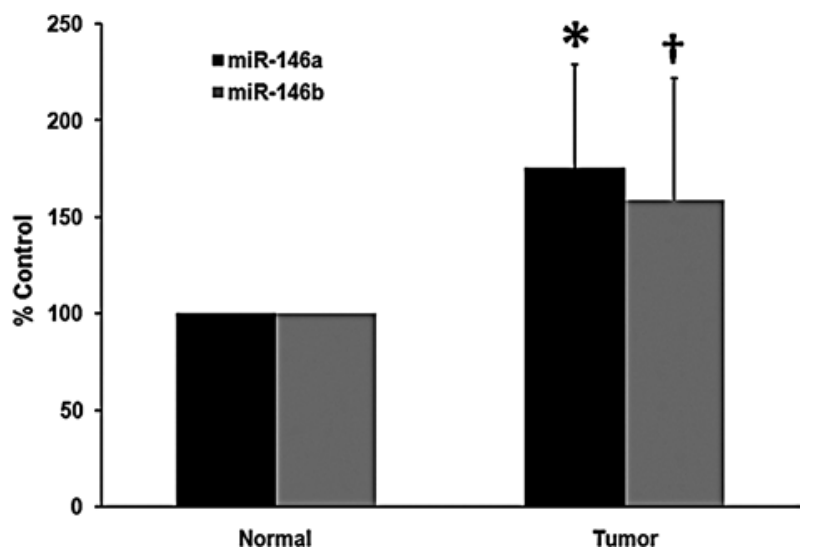

Figure 3. Expression levels of miR-146a and miR-146b in human renal cell carcinoma ( ${ }^{*} \mathrm{p}<0.05$ vs. miR-146a and ${ }^{\dagger} \mathrm{p}<0.05$ vs. miR-146b in normal lesions of renal cell carcinoma).

with Alb $(500 \mu \mathrm{g} / \mathrm{ml})$ or cAlb (100 and $500 \mu \mathrm{g} / \mathrm{ml})$, miRNA microarray analysis was performed.

After normalizing the data, miRNAs up- or downregulated by $>2$-fold were analyzed. Notably, no miRNAs were found to be down-regulated $>2$-fold by cAlb treatment. miRNAs up-regulated $>2$-fold by cAlb are listed in Table I. Of the up-regulated miRNAs, miR-21*, miR-21 and miR-222 were excluded from further study since albumin-stimulated miR-21 and miR-222 were up-regulated >2-fold and miR-21* was up-regulated close to 2-fold. Consequently, expression of
Table II. Demographics and clinical variables of renal cell carcinoma patients $(n=22)$.

Sex (male:female)

Age (mean value $\pm \mathrm{SD})$

Type

Clear cell renal cell carcinoma

Stage

I

II

III

$\mathrm{SD}$, standard deviation.

miR-146a and miR-146b in Alb- or cAlb-treated RMCs was evaluated by quantitative real-time RT-PCR analysis.

Effect of cAlb on miR-146a and miR-146b expression in rat mesangial cells. The expression of miR-146a and miR-146b was investigated by real-time RT-PCR (Fig. 2). In Alb-treated RMCs, the expression of miR-146a and miR-146b was $119 \pm 25 \%$ and $129 \pm 44 \%$, respectively, compared to the control. Significantly higher expression of miR-146a and miR-146b (miR-146a, 414 $\pm 83 \%$; miR-146b, 175 $\pm 63 \%$, p<0.05) was observed in cAlb $(100 \mu \mathrm{g} / \mathrm{ml})$-treated RMCs. Treatment with $500 \mu \mathrm{g} / \mathrm{ml} \mathrm{cAlb}$ dramatically stimulated the expression of miR-146a $(903 \pm 182 \%, \mathrm{p}<0.05)$ and miR-146b $(460 \pm 121 \%$, $\mathrm{p}<0.05)$ in a dose-dependent manner. These data indicate that both miR-146a and miR-146b are significantly induced by cAlb in RMCs.

miR-146a and miR-146b expression in renal cell carcinoma. Next, the expression levels of miR-146a and miR-146b in human renal cell carcinoma were determined, since altered expression of miR-146a and miR-146b, to the best of our knowledge, has not been previously reported. As described in Materials and methods, 22 renal cell carcinoma specimens including tumor and non-tumor lesions from the same patient were obtained from the Keimyung Human Bio-Resource Bank. Demographics and clinical variables of renal cell carcinoma patients are listed in Table II. As shown in Fig. 3, compared to the corresponding non-tumor lesions, expression levels of miR-146a and miR-146b were markedly increased 
(miR-146a, 175.2 $\pm 54.0 \%$; miR-146b, 158.6 $\pm 63.5 \%, \mathrm{p}<0.05$ ). Due to the limited sample size, an association between the expression levels of miR-146a and miR-146b and tumor stage was not determined. We are currently in the process of obtaining IRB approval for further studies with an extended number of tumor samples.

\section{Discussion}

It is well recognized that post-translational modifications, such as phosphorylation, glycosylation, acetylation and sumoylation, control various biological and pathologic processes (14). Cyanate, which binds to $\mathrm{NH}_{2}$ groups of proteins - in particular $\varepsilon-\mathrm{NH}_{2}$ groups of lysine residues, thereby inducing the carbamylation of protein - is generated by spontaneous dissociation from urea. Concentrations of carbamylated protein are extremely low when normal plasma levels of urea are present. Therefore, the molecular mechanisms underlying the pathological effects of carbamylated proteins, in comparison with other post-translational modifications such as glycosylation in diabetes mellitus, has received limited attention.

Few in vitro studies with carbamylated protein have been reported. Increased amounts of carbamylated proteins in blood and tissues have been documented in CRF (15-17). Studies have evaluated the effect of carbamylation on the structure and/or function of proteins, enzymes or hormones $(4,18,19)$. Both uremic LDL and carbamylated LDL have been implicated in multiple proatherosclerotic biological effects $(3,16)$. Carbamylated collagen was shown to stimulate the production of active matrix metalloproteinase- 9 by blood monocytes (20), and carbamylated collagen as well as carbamylated albumin were also demonstrated to inhibit the respiratory burst of PMNs $(12,21)$. One study demonstrated that carbamylated serum proteins activate mesangial cells to a profibrogenic phenotype (22).

In the present study, we investigated the effect of cAlb on the differential expression of miRNAs in RMCs. The results indicate that the effect of cAlb on miRNAs is an increase in their expression, which is commonly observed in solid tumors (23). cAlb was found to markedly stimulate miR-146a and miR-146b expression (Table I). It was also confirmed using quantitative real-time RT-PCR analysis that cAlb-induced miR-146a and miR-146b expression is significantly increased (Fig. 2). A rapidly growing body of evidence indicates that miRNAs play important roles in development, disease and evolution. Although numerous endogenous miRNAs implicated in various diseases have been identified, the number is likely to increase substantially since commercial miRNA profiling platforms have recently become available, making possible the detection of as yet undiscovered miRNAs. The number of known human miRNAs is thus continuously increasing, rendering even the most recently published studies incomplete.

Given the prominent biological importance of miRNAs, understanding their mode of action and their physiological roles is essential. However, the specific functions of many identified endogenous miRNAs remain to be defined. Taganov et al (24) reported that $\mathrm{miR}-146 \mathrm{a} / \mathrm{b}$ are induced in response to lipopolysaccharide and proinflammatory mediators, and that miR-146a induction is regulated by NF- $\kappa B$. They also found that $\mathrm{miR}-146 \mathrm{a} / \mathrm{b}$ targets include TNF receptor-associated factor 6 (TRAF6) and IL-1 receptor-associated kinase 1 (IRAK1) genes, and concluded that miR-146 plays a role in the fine-tuning of innate immune responses by negative feedback, including the down-regulation of the TRAF6 and IRAK1 genes. miR-146a and miR-146b have recently been shown to inhibit migration and invasion (25). BRMS1, a metastasis suppressor that regulates the expression of multiple genes, significantly increased miR-146 expression. Therefore, cAlb may be involved in renal pathophysiology, particularly in renal cell carcinoma, by differentially regulating the expression of miR-146a and miR-146b.

In summary, we provide evidence that cAlb stimulates miR-146a and miR-146b expression in rat mesangial cells, and that the expression of miR-146a and miR-146b is increased in renal cell carcinoma. This study is the first to report the regulatory effect of cAlb on miRNAs. We are currently investigating the functional relationship between $\mathrm{cAlb}$ and renal cell carcinoma with a more extended number of samples. Further studies to develop miRNA-based therapies will follow.

\section{Acknowledgements}

This study was supported by a 2009 research grant from the Dongsan Kidney Institute, Keimyung University.

\section{References}

1. Erill S, Calvo R and Carlos R: Plasma protein carbamylation and decreased acidic drug protein binding in uremia. Clin Pharmacol Ther 27: 612-618, 1980.

2. Fluckiger R, Harmon W, Meier W, Loo S and Gabbay KH: Hemoglobin carbamylation in uremia. $\mathrm{N}$ Engl $\mathrm{J}$ Med 304: 823-827, 1981.

3. Hörkkö S, Huttunen $K$, Kervinen $K$ and Kesäniemi YA: Decreased clearance of uraemic and mildly carbamylated lowdensity lipoprotein. Eur J Clin Invest 24: 105-113, 1994.

4. Kraus LM and Kraus AP Jr: Carbamoylation of amino acids and proteins in uremia. Kidney Int 78: S102-S107, 2001.

5. Wang Z, Nicholls SJ, Rodriguez ER, Kummu O, Hörkkö S, Barnard J, Reynolds WF, Topol EJ, DiDonato JA and Hazen SL: Protein carbamylation links inflammation, smoking, uremia and atherogenesis. Nat Med 13: 1176-1184, 2007.

6. Ambros V: The functions of animal microRNAs. Nature 431: 350-355, 2004.

7. Bartel DP: MicroRNAs: genomics, biogenesis, mechanism and function. Cell 116: 281-297, 2004

8. Farh KK, Grimson A, Jan C, Lewis BP, Johnston WK, Lim LP, Burge CB and Bartel DP: The widespread impact of mammalian microRNAs on mRNA repression and evolution. Science 310: 1817-1821, 2005.

9. Lu J, Getz G, Miska EA, Alvarez-Saavedra E, Lamb J, Peck D, Sweet-Cordero A, Ebert BL, Mak RH, Ferrando AA, Downing JR, Jacks T, Horvitz HR and Golub TR: MicroRNA expression profiles classify human cancers. Nature 435: 834-838, 2005.

10. Marcucci G, Radmacher MD, Maharry K, Mrózek K, Ruppert AS, Paschka P, Vukosavljevic T, Whitman SP, Baldus CD, Langer C, Liu CG, Carroll AJ, Powell BL, Garzon R, Croce CM, Kolitz JE, Caligiuri MA, Larson RA and Bloomfield CD: MicroRNA expression in cytogenetically normal acute myeloid leukemia. $\mathrm{N}$ Engl J Med 358: 1919-1928, 2008.

11. Pfeffer S, Zavolan M, Grasser FA, Chien M, Russo JJ, Ju J, John B, Enright AJ, Marks D, Sander C and Tuschl T: Identification of virus-encoded microRNAs. Science 304: 734-736, 2004.

12. Jaisson S, Delevallée-Forte C, Touré F, Rieu P, Garnotel R and Gillery P: Carbamylated albumin is a potent inhibitor of polymorphonuclear neutrophil respiratory burst. FEBS Lett 581: 1509-1513, 2007. 
13. Hörkkö S, Savolainen MJ, Kervinen K and Kesäniemi YA: Carbamylation-induced alterations in low-density lipoprotein metabolism. Kidney Int 41: 1175-1181, 1992.

14. Tate EW: Recent advances in chemical proteomics: exploring the post-translational proteome. J Chem Biol 1: 17-26, 2008.

15. Oimomi M, Ishikawa K, Kawasaki T, Hatanaka H, Ishikawa $\mathrm{K}$, Kawasaki T, Yoshimura Y and Baba S: Carbamylated plasma protein in renal failure. Nippon Jinzo Gakkai Shi 28: 269-271, 1986.

16. Ok E, Basnakian AG, Apostolov EO, Barri YM and Shah SV: Carbamylated low-density lipoprotein induces death of endothelial cells: a link to atherosclerosis in patients with kidney disease. Kidney Int 68: 173-178, 2005.

17. Kraus LM, Gaber L, Handorf CR, Marti HP and Kraus AP Jr: Carbamoylation of glomerular and tubular proteins in patients with kidney failure: a potential mechanism of ongoing renal damage. Swiss Med Wkly 24: 139-145, 2001.

18. Mun KC and Golper TA: Impaired biological activity of erythropoietin by cyanate carbamylation. Blood Purif 18: 13-17, 2000.

19. Jaisson S, Larreta-Garde V, Bellon G, Hornebeck W, Garnotel R and Gillery P: Carbamylation differentially alters type I collagen sensitivity to various collagenases. Matrix Biol 26: 190-196, 2007.

20. Garnotel R, Sabbah N, Jaisson S and Gillery P: Enhanced activation and increased production of matrix metalloproteinase- 9 by human blood monocytes upon adhering to carbamylated collagen. FEBS Lett 563: 13-16, 2004.
21. Jaisson S, Lorimier S, Ricard-Blum S, Sockalingum GD, Delevallée-Forte C, Kegelaer G, Manfait M, Garnotel R and Gillery P: Impact of carbamylation on type I collagen conformational structure and its ability to activate human polymorphonuclear neutrophils. Chem Biol 13: 149-159, 2006.

22. Shaykh M, Pegoraro AA, Mo W, Arruda JA, Dunea G and Singh AK: Carbamylated proteins activate glomerular mesangial cells and stimulate collagen deposition. J Lab Clin Med 133: 302-308, 1999

23. Volinia S, Calin GA, Liu CG, Ambs S, Cimmino A, Petrocca F, Visone R, Iorio M, Roldo C, Ferracin M, Prueitt RL, Yanaihara N, Lanza G, Scarpa A, Vecchione A, Negrini M, Harris CC and Croce CM: A microRNA expression signature of human solid tumors defines cancer gene targets. Proc Natl Acad Sci USA 103: 2257-2261, 2006.

24. Taganov KD, Boldin MP, Chang KJ and Boltimore D: NF- $\mathrm{KB}$-dependent induction of microRNA miR-146, an inhibitor targeted to signaling proteins of innate immune responses. Proc Natl Acad Sci USA 103: 12481-12486, 2006.

25. Hurst DR, Edmonds MD, Scott GK, Benz CC, Vaidya KS and Welch DR: Breast cancer metastasis suppressor 1 up-regulates miR-146, which suppresses breast cancer metastasis. Cancer Res 69: 1279-1283, 2009. 